Int. J. Electrochem. Sci., 12 (2017) 9150 - 9160

\title{
High Sensitive Electrochemical Quantification of Isoniazid in Biofluids Using Copper Particles Decorated Graphene Oxide Nano Composite
}

\author{
T.S.T. Balamurugan ${ }^{1}$, Kesavan Manibalan ${ }^{1}$, Shen-Ming Chen ${ }^{1, *}$, Paramasivam Balasubramnian ${ }^{1}$, \\ Sheng-Tung Huang ${ }^{1,2, *}$ \\ ${ }^{1}$ Department of Chemical Engineering and Biotechnology, National Taipei University of Technology, \\ No.1, Section 3, Chung-Hsiao East Road, Taipei 106, Taiwan \\ ${ }^{2}$ Institute of Biochemical and Biomedical Engineering, National Taipei University of Technology, \\ No.1, Section 3, Chung-Hsiao East Road, Taipei 106, Taiwan \\ *E-mail: smchen78@ms15.hinet.net \\ *E-mail: ws75624@ntut.edu.tw
}

doi: $10.20964 / 2017.10 .44$

Received: 7 July 2017 / Accepted: 4 August 2017 / Published: 12 September 2017

The excessive consumption and harming side effects of chemical antibiotics and NSAIDs are lead to the necessity of a simple analytical tool for high sensitive, quantitative detection of hepatotoxic drugs in human body fluids. In this work, we report an electrochemical sensor constructed by the facile electrochemical deposition of copper micro particles over graphene oxide nanosheets modified glassy carbon electrode and their potential application towards quantitative detection of isoniazid (isonicotinylhydrazide INH) (hepatotoxic drug) in bio fluids. The constructed $\mathrm{Cu} / \mathrm{GO} / \mathrm{GCE}$ electrode was further characterized by SEM, EDX, and Raman spectroscopy. As constructed electrode displayed excellent synergy and enhanced electrocatalytic activity towards INH. The described sensing platform of INH exhibits low limit of detection (LOD) $23.4 \mathrm{nM}$ and wide linear range $0.15 \mu \mathrm{M}-500 \mu \mathrm{M}$ with high sensitivity of $1.2394 \mu \mathrm{A} \mu \mathrm{M}^{-1} \mathrm{~cm}^{-2}$. The practical feasibility of the $\mathrm{Cu} / \mathrm{GO} / \mathrm{GCE}$ electrode is demonstrated in urine, and human serum sample with direct spiking of INH and achieved good recoveries.

Keywords: Hepatotoxic drugs, Isoniazid, Graphene oxide nanocomposite, Electrocatalysis, Bio-fluid analysis.

\section{$\underline{\text { FULL TEXT }}$}

(C) 2017 The Authors. Published by ESG (www.electrochemsci.org). This article is an open access article distributed under the terms and conditions of the Creative Commons Attribution license (http://creativecommons.org/licenses/by/4.0/). 